\title{
The Future of Corporate Bonds - Collateral, Risks, New Legal Regulations
}

\author{
Ewa Ciborowska*
}

\begin{abstract}
Summary
The following article presents corporate bonds as one of the important ways for entrepreneurs to obtain financing. There were presented the risks of corporate bonds investors i.e. disproportion of information and significant risks occurring mainly on the retail investors. Besides the author presented the new regulations of Act on Bonds which ensure greater security of trading on the bond market. The Act is intended to strengthen control over the bond market through dematerialization and registration of all bond issues in the National Depository for Securities (KDPW), which until now existed only for public offers. The research study results included in the article should contribute to filling the significant gap in the literature of the subject and facilitate conducting analysis of corporate bonds market in Poland.
\end{abstract}

Keywords: Bonds, Risk, Securities, Issuers, Collateral

JEL: K22

\section{INTRODUCTION}

Corporate bonds issue is considerably more flexible debt financing method than the bank credit, in which the entrepreneur in the Terms and Conditions of the Issue of Bonds (WEO) defines the rules under which he incurs a liability. The abovementioned advantages made bonds an exceptionally common form of raising capital.

The subject literature referring to the financial markets provides a wide variety of terms defining bonds. In the case of corporate bonds, there is no unambiguous definition of this concept under the applicable law. A corporate bond is a security in the rank of dispersed debt issued by a company conducting business activity in order to collect medium- and long-term loan funds securing the investment activity of the issuer of this instrument (Pawłowski, 2015). This definition should be seen in the context of the economic function of corporate bonds, as the legal nature of bonds as a financial instrument is precisely described by legal acts (Pawłowski, 2015; Pawłowski, 2011). Thus, the bond states the existence of debt of the issuer - entrepreneur - to the purchaser of the bonds - investor (bondholder) (Dybowski \& Pyrzyńska, 2006).

\section{CORPORATE BONDS - LEGAL REGULATIONS}

Enterprises issue bonds in order to raise the capital necessary to carry on the activity, its development or new investments. Bond buyers, in turn, are entitled to receive interest and return capital at maturity of the bonds. Importantly, unlike shares, bonds generally do not give the purchaser any other rights towards the issuer. Therefore, a corporate bond does not include dividend rights or the right to participate and vote in a general meeting. Neither does the acquirer of the bonds become a co-owner of the company. It is worth adding, however, that certain types of corporate bonds may be associated with special rights (e.g. convertible bonds entitle to take up shares issued by the company in exchange for these bonds), including those of a property nature (e.g. participating bonds grant the right to participate in the issuer's profit) and of a corporate nature (where the terms of

Legal counsel, Ph.D Student at University of Warsaw, Faculty of Management, Poland; e-mail: 392078@uw.wz.edu.pl 
issue provide for a meeting of bondholders, which is entitled to adopt resolutions relevant from the point of view of the bondholders' interests). The bonds are issued in series, divided into a certain number of equal units representing the same property rights (e.g. company $\mathrm{X}$ issues 70 series $\mathrm{A}$ bonds with a nominal value of PLN 10,000 each, thus acquiring PLN 700,000, and 80 series B bonds with a nominal value of PLN 20,000 each, thus acquiring PLN 1,600,000).

\section{Bond issue procedures}

We distinguish the following bond issue modes: ${ }^{1}$

1) non-public placement also referred to as a private or closed issue

2) public issue conducted in accordance with the provisions of the Act on Public Offering and Conditions Governing the Introduction of Financial Instruments to Organized Trading and Public Companies

Private placement mode constitutes an offer to purchase corporate bonds addressed to a group of individually designated addressees in a number not exceeding 149 entities. Literature indicates that a non-public offering of debt securities is conducted through the issuer's declaration of intent to conclude an agreement by way of an offer, invitation to negotiations or a tender limited by a circle of selected investors. In practice, as part of a private placement, the offer is addressed to several or more than a dozen entities with which individual negotiations are conducted (Michalak, 2007).

\section{STATUTORY SECURITIES OF BONDHOLDERS}

In order to secure bondholders in the event of a closed issue, a statutory obligation has been introduced to disclose by the issuer information describing the issue and the issuer's property and financial situation (Cichy, 2012).

Information obligations resulting from the Act on Bonds are one of the collaterals that protect investors: "An issuer conducting business activity for more than one year is obliged to make available, in a purchase proposal, financial statements prepared as at the balance sheet date falling not earlier than 15 months before the date of making the purchase proposal available together with an audit report". Moreover, "in the period between the issue of bonds and the full redemption of bonds, the issuer shall make the annual financial statements and the audit report available to the bondholders". ${ }^{2}$

In the case of a public issue, investors have been secured by a statutory obligation to prepare a prospectus or information memorandum - if the issuer, within 12 months preceding the new issue, placed bonds with a total nominal value not exceeding EUR 2,500,000 or the issued bonds are guaranteed unconditionally and irrevocable by the State Treasury or administrative bodies of EU countries. Both the prospectus and the information memorandum are subject to approval by the Polish Financial Supervision Authority.

\section{RISKS FOR CORPORATE BONDS INVESTORS}

Taking into consideration the existing regulations, it should be pointed out that despite the above described information obligations incumbent on issuers on the bond market, there is an information asymmetry, which is why investors (including financial institutions) are exposed to abuses committed by issuers. The particularly privileged position of corporate bond issuers towards investors in terms of access to information creates a particular risk of moral hazard (Gradoń, 2014).

Article 33 of the Act on Bonds of 15 January 2015 (Journal of Laws of 2015, item 238, as amended).

Article 35 of the Act on Bonds (Journal of Laws 2015, item 238, as amended) 
Moreover, investors are exposed to other types of risk, in particular: interest rate risk, reinvestment risk, early redemption risk, inflation risk, foreign exchange risk and, above all, credit risk and liquidity risk.

Liquidity risk is the most important type of risk and occurs when the issuer of bonds is unable to service the debt incurred by issuing them (i.e. it is unable to meet interest payments on time or fails to meet its commitments at all). On the other hand, the credit risk borne by the bondholder is difficult to estimate, especially in the case of the market in the initial development phase. However, its level depends on two basic factors:

1) the probability of insolvency of the issuer, whereby not only the non-repurchase of the nominal value but also the delay in the payment of interest are treated as insolvency,

2) recovery rate, i.e. the part of the claims that can be recovered in the event of suspension of debt service.

The ratings of credit rating agencies can help to assess credit risk, especially in a context of an increasing number of issuers (Cichy, 2009).

It should be pointed out that, under the current rules, issuers have a great deal of leeway in determining the parameters of the issue, this refers in particular to the definition of nominal value, interest rate level, interest payment, maturity, issue price. Moreover, in the case of corporate bonds, entrepreneurs have more freedom in choosing the form of collateral than in the case of bank credit. According to the Grant Thornton report from June 2018, among the issues introduced on Catalyst in 2017 , covered bonds accounted for $34.2 \%$. The share of unsecured issues in the structure of corporate issues increased to $57.5 \%$ compared to 2016 . Until the end of 2017 , issuers most often chose pledge (34.3\%) and mortgage (32.8\%) as collateral, the less frequently used form of collateral was assignment of receivables and receivables. ${ }^{3}$

In addition, the Issuer may also undertake to the bondholders to provide non-cash benefits, e.g. conversion of bonds into shares (the so-called convertible bonds) or granting the bondholder a preemptive right to acquire new issue shares (Gradoń, 2014).

Bonds may be offered by the issuer in two market areas:

1) non-organized market

2) Catalyst organized market

A non-organized market should be understood as any form of trading in financial instruments which, in the light of the applicable regulations, does not constitute organized trading (Pawłowski, 2015).

The offering of debt securities on the non-organized market is characterized by a lack of transparency and access to information, which in consequence poses a higher risk for investors due to the lack of transparency of the offer. To a large extent, the above lack of transparency is related to the lack of issuer's information standards. The statutory obligation to present annual financial statements with an auditor's opinion is insufficient for a thorough analysis and for taking appropriate decisions by investors. When assessing a non-organized secondary market, the lack of standardization of debt parameters, in particular the nominal value, interest rate, maturity and security method, must be stressed (Pawłowski, 2015).

At the end of the fourth quarter of 2017 , the number of corporate bonds increased by $8.3 \%$, the number of mortgage bonds by $13.3 \%$, and the number of municipal bonds by a record $10.2 \%$. Similarly to 2016, the number of cooperative bonds decreased in 2017 by $5.6 \%$. Excluding Treasury bonds from the analysis, the number of debt instruments listed on Catalyst at the end of 2017 amounted to 567 series, i.e. by 43 series more than in the previous year.

3 Catalyst Report - Development Summary, GrantThornton Frąckowiak Sp. z o.o. sp. k., Poznań 2017 
According to experts from Aforti Holding S.A., corporate bonds with a total value of PLN 86.5 billion were listed on the Catalyst market at the end of November 2018. Therefore, over the last year, the debt securities market recorded an increase by PLN 14.2 billion, which is a continuation of the upward trend that has been going on for several years.

Figure 1. Structure of value of instruments listed on Catalyst (in PLN) by type of instruments as at 31 December 2017 (excluding treasury bonds)

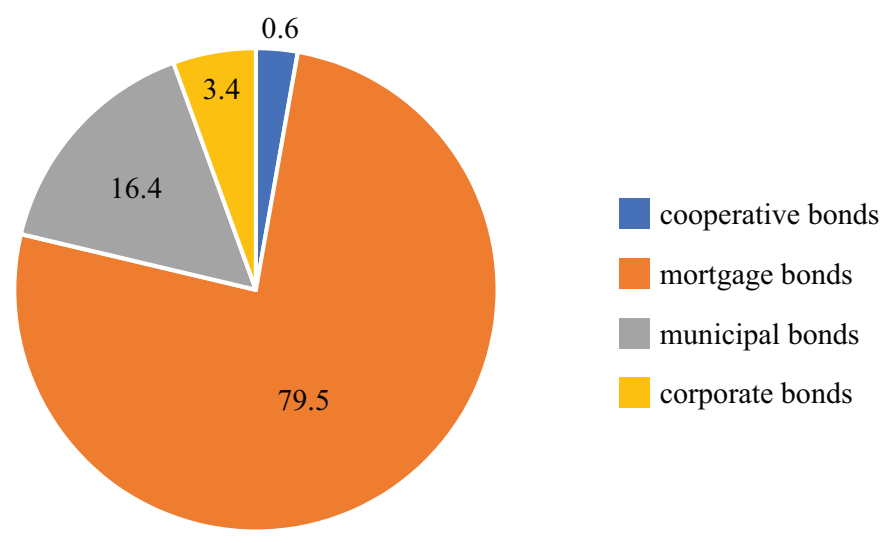

Source: Catalyst - Grant Thornton Frąckowiak Sp. z o.o. Sp. k. report, Poznań 2017

Transparency of the Polish financial instruments market is particularly crucial in the context of the development of the bond market and is steadily increasing due to the changes introduced in regulations. Issuers are obliged to report all significant events affecting their financial, property and economic standing, thus enabling investors to assess the current condition of the issuer in terms of the ability to meet the commitments made to them. When analyzing the Catalyst market, it is impossible to ignore situations in which investors' trust has been undermined. If the issuer allows a situation in which default is unavoidable, lacking reliable information and disregarding the interests of investors at the same time, then the credibility of future issues is reduced and the investment risk of debt securities increases. An event that touched the capital market in 2018, i.e. GetBack's failure to meet its obligations, may raise concerns about the credibility of Catalyst market issuers, let alone companies issuing bonds that are not and will not be traded on the public market.

According to the Grant Thornton Report, bonds listed on the Catalyst market constituted only a part of the debt issued by the company ${ }^{1}$. In Poland, there have already been situations of problems with the repayment of corporate bonds. Therefore, when assessing the Catalyst market, the above situation should not be underestimated, and conclusions should be drawn for the future without, however, assessing the market from the perspective of one issuer.

The above situations indicate the need for greater financial transparency of entities issuing bonds, in particular, according to the author of this article, the scope of financial information provided to investors in purchase proposals and subsequently within the framework of the disclosure obligations set out in the Terms and Condition of Bonds issue should be wide enough for investors to be able to manage investment risk based on the financial data provided. Regular provision of a wider range of financial information throughout the funding period until redemption is crucial for both retail and institutional investors. The statutory obligation to present annual financial statements with an auditor's opinion may not be considered sufficient for investors' decisions, especially in a changing market environment (Pawłowski, 2015). At the same time, observation of the functioning of the secondary non-organized market indicates that this market is also not fully transparent and lack of

Catalyst Report 2017 - Development Summary. GrantThornton Frąckowiak Sp. z o.o. sp. k. 
standardization of issue parameters makes it difficult to compare instruments of different issuers (Piwowar, 2009).

The Polish corporate bond market is dominated by private placements. In 2017, according to Fitch Polska, entrepreneurs issued debt securities worth PLN 14.9 billion, including debt securities in prospectus offers for less than PLN 1.9 billion. It should be noted that Fitch collects data only on those issues, which are communicated to it mainly by brokerage houses, therefore it is estimated that not only the corporate bond market is much larger than the official data, but also the share of public issues is even smaller, clearly below $10 \%$ of the total number of issues ${ }^{2}$.

According to Fitch Polska data, the vast majority of bond issues in Poland are conducted in a private placement mode. This is due to the fact that they are sufficient to carry out institutional issues and small issues addressed to individual investors. Moreover, the existing regulations on private placement have enabled relatively fast and cheap acquisition of financing by issuers.

\section{NEW LEGAL REGULATIONS}

In relation to the strengthening of supervision over the financial market and protection of investors in this market, on 29 November 2018 the Act of 9 November 2018 amending certain acts was signed by the President of the Republic of Poland. The Act is intended to strengthen control over the bond market and introduces key changes, in particular with respect to corporate bond issues. The amendment introduces the obligation to dematerialize and register all bond issues in the National Depository for Securities (KDPW), which until now existed only for public offers.

The Act imposes on the entrepreneurs issuing corporate bonds by way of private placement, for which the issuer does not intend to apply for admission to trading on the regulated market or introduction to the ATS, prior to concluding an agreement for registration of these securities in the depository for securities, concluding an agreement for the performance of the role of an agent for the issue of these securities with an investment company authorized to maintain securities accounts or with a custodian bank. Pursuant to the Act, an agreement on the performance of the role of an issue agent is concluded prior to the commencement of the offer to purchase securities.

In the light of the amended Act on Bonds, the duties of an issue agent include in particular:

1) verification of the issuer's compliance with the requirements concerning the issue of securities, resulting from the provisions of law;

2) verification of the issuer's compliance with the requirements for offering securities resulting from legal regulations;

3) verification that securities and their issuer meet the conditions for registration in the depository for securities set out in the regulations referred to in Article 50.1, as well as whether the rules for handling issuers' obligations ensure proper performance of obligations arising from securities adopted by the National Depository or by a company to which the National Depository has delegated the performance of activities related to tasks referred to in Article 48.1.1 and 48.1.4;

4) creation of a register of persons entitled under securities;

5) acting as an intermediary in the conclusion by the issuer of an agreement concerning the registration of securities in the depository for securities, in particular providing the issuer with the necessary assistance in determining and preparing the documentation necessary for the conclusion of such agreement.

The introduction of the role of an issue agent was aimed at facilitating the process of registration of debt securities in a depository. On the other hand, capital market participants argue that this change

2 https://www.parkiet.com/Obligacje/305129965-Rewolucja-w-sprzedazy-obligacji-firm.html 
may lead to an increase in the cost of issue and, in combination with the obligation to register private placement bonds in KDPW, may result in the reduction or even disappearance of short-term bond issues from the market. These bond market changes enter into force on 1 July 2019.

\section{SUMMARY}

Corporate bonds are one of the important ways for entrepreneurs to obtain financing. To a large extent, in view of the speed and low costs of obtaining financing, the bond market in Poland is growing year by year and this way of obtaining financing is becoming more and more attractive in relation to bank loans or share issues. On the other hand, due to the disproportion of information and significant risks occurring mainly on the retail investors' side, it is important to secure them in an appropriate way, which, however, will not limit private issues and will allow for further development of this market. Let's hope that the amended Act on Bonds will ensure greater security of trading on the bond market and will not reduce private issues.

\section{Literature}

Cichy, J. (2012). Bank spółdzielczy na rynku obligacji Catalyst w Polsce. Wspótczesna bankowość spółdzielcza. Warszawa: CeDeWu.

Cichy, J. (2009). Rola oceny ratingowej $w$ decyzjach finansowych polskich przedsiębiorstw. Rynki finansowe w rozwoju podmiotów gospodarczych. Warszawa: Difin.

Dybowski, T. Pyrzyńska, A. (2006). Świadczenie pieniężne. Prawo zobowiazań - część ogólna. System prawa prywatnego. Warszawa: C.H. Beck.

Gradoń, W. (2014). Emisja obligacji korporacyjnych a ryzyko uczestników rynku korporacyjnego. Katowice: Wydawnictwo Uniwersytetu Ekonomicznego w Katowicach.

Michalak, A. (2007). Finansowanie inwestycji w teorii i praktyce. Warszawa: PWN.

Pagano, M. Jappelli, T. (2013) Financial Integration in Europe. In The Evidence and Impact of Financial Globalization. Oxford: Elsevier Inc.

Pawłowski, M. (2015). Rynek obligacji korporacyjnych w Polsce „Uwarunkowania i perspektywy rozwoju” Warszawa: CeDeWu.pl.

Pawłowski, M. (2011). Rynek krótkoterminowych papierów dłużnych przedsiębiorstw w Polsce. Zeszyty Naukowe Uniwersytetu Szczecińskiego Nr 639, Finanse. Rynki finansowe. Ubezpieczenia. Nr 37, Kraków: Drukarnia Wydawnicza im. W.L. Anczyca SA.

Piwowar, M.S. (2009). Corporate and Municipal Bond Market Microstructure in the U.S.; Complex Systems in Finance and Econometrics. New York: Meyers, SpringerScience+Business Media, LCC.

2017 Raport Catalyst - podsumowanie rozwoju. GrantThornton Frąckowiak Sp. z o.o. sp. k. Pozyskano z: https://grantthornton.pl/wp.../Raport-Catalyst-GRANT-THORNTON-18-06-2018.pdf

2017 Raport Fitch Ratings Global Corporate Finance 2017 Transition and Default Study. Special Report. Fitch Ratings 2017. Pozyskano z: https://www.fitchratings.com/site/poland

https://www.parkiet.com/Obligacje/305129965-Rewolucja-w-sprzedazy-obligacji-firm.html 